\title{
Analysis Porter's Five forces Model on Airbnb
}

\author{
Osiany Nurlansa \\ Electronics and Informatics Engineering Education, Yogyakarta State University \\ E-mail : Osikura@gmail.com
}

\begin{abstract}
This paper discusses about Airbnb. Airbnb is a company website that allows ordinary people to rent their residence as tourist accommodation. Anyone can rent rooms to suit their budget. The company established in 2008, and eight years later by a very rapid growth, the company reaches a turnover of millions of rooms per year. Airbnb analyzed using Porter's Five Forces Model. According to Porter, the competitive nature of the industry could be seen as a combination of top five strengths, namely Rivalry Among Existing Competitors, Threat of New Entrants, Threat of substitude Products or Services, Bargaining Power of Suppliers, Bargaining Power of Buyers. Data were processed using descriptive analysis. Analysis Airbnb terms of Porter's Five Forces Model concluded that from the fifth models of Porter, Rivalry Among Existing Competitors system, Threat of New Entrants, Threat of substitude Products or Services, Bargaining Power of Buyers robust system and one student Bargaining Power of Suppliers found to be very weak
\end{abstract}

Keywords: porter's five forces model, airbnb, ecommerce

\section{INTRODUCTION}

The development of the industrial world is rapidly increasing competition. In the 21 st century, the development of an industry or a company driven by the information system to serve its customers. Companies that do not want to grow in terms of information systems, will gradually abandoned by the customer because it is felt to be ineffective and less helpful or interactive. Marketplace various and has so many themes to rival similar-similar or nearly identical in features and services offered. One of the Airbnb marketplace success in the achievement to date, although in 2009 was declared bankrupt, but Airbnb can prove that the company can survive. They even changed that they do outside the usual reasoning of others so that people thinking behind Airbnb is very creative.

Airbnb is an online marketplace for people who want to rent and rent out private rooms, apartments or homes. Airbnb (www.airbnb.co.uk) is an accommodationrental service for people who want to rent or rent out a spare room, house or flat for a short stay. Instead of booking into a hotel or B\&B, users stay in other people's properties, potentially enjoying a more quirky and personal experience [1]. Usually, people are renting out her house on a daily basis like a hotel room. For owners of a room, apartment or house, this could be an additional income. And for users / guests, this could be one alternative to get local experience and accommodations are less expensive than staying in hotels.

"Competition is the essence of success". Competition among peers is very sharp, new competitors may enter the industry with relative ease, as well as suppliers and customers can increase their bargaining power [17]. In order to win every competition, every company should have a competitive strategy. The final goal is the competitive strategy for tackling the environmental forces in the interest of the company. Competitive strategy is often called the business strategy, focused on improving the competitive position of the 
products and services of companies in the industry or a particular market segment served companies [8]. Competitive strategy is the search for a favorable competitive position in an industry, the fundamental arena in which competition lasts. Competitive strategy aimed at fostering a favorable position and strong in fighting the forces that determine competition in the industry. Therefore, the competitive strategy is not only a response to the environment but also the effort to establish the environment in accordance with the wishes of the company [18].

That Airbnb entered in the Best side businesses to fund your startup, stated that, offering up your accommodations through Airbnb, the web and app-based service that connects travelers with hosts, who then open Reviews their house as an impromptu hotel. Airbnb makes a great side business for the social butterfly who enjoys making connections and meeting new people. In addition to consulting, Diana Melencio funded OkMyOutfit by renting out her guest room for travelers. "I rent out my guest bedroom for supplemental income," she said. "Along the way, I've had some incredible guests that I remain in touch with." If you have extra space in a coveted part of the country (if you live in smalltown, USA, this might be a less viable option), you would be wise to consider Airbnb. Not only will it provide a relatively low-effort supplemental income source, but you might come across some interesting networking opportunities along the way. [15] Seeing the rapid growth Airbnb, the authors analyze Airbnb if the terms of five forces analysis Porter on Airbnb.

\section{THEORETICAL BACKGROUND}

\section{e-Commerce}

Electronic Commerce (E-Commerce) is a new concept that is usually described as the process of buying and selling goods or services on the World Wide Web Internet [14] or the process of buying and selling or exchange of products, services and information through information networks including the Internet [14].

e-Commerce from several perspectives following [14]

- Perspective Communications: eCommerce is indormasi delivery, product / service, or payments over telephone lines, computer network or other electronic means.

- Business Process Perspective: eCommerce is the application of automation technology to the transaction and the company's work flow.

- Perspective Services: e-Commerce is one tool that meets the needs of companies, consumers and management to cut service costs while improving the quality of goods and speed of service

- Perspective Online: e-Commerce related to the capacity of buying and selling of products and information on the Internet and other online services.

Classification of e-Commerce is commonly done is based on the nature of the transaction. immediately following types can be distinguished [14]

- Business to Business (B2B)

- Business to Consumer (B2C)

- Consumer to Consumer (C2C)

- Consumer to Business (C2B)

For some people, the term e-Commerce interpreted narrowly as sale and purchase transactions of products, services and information between business partners over 
computer networks, including the Internet. eCommerce will change all marketing activities and also while cutting operational costs for trading (trading).

There are four business models: Asset Builders: these companies build, develop, and lease physical assets to make, market, distribute, and sell physical things. Examples include Ford, Wal-Mart, and FedEx. Service Providers: these companies hire employees who provide services to customers or produce billable hours for which they charge. Examples include United Healthcare, Accenture, and JP Morgan. Technology Creators: these companies develop and sell intellectual property such as software, analytics, pharmaceuticals, and biotechnology. Examples include Microsoft, Oracle, and Amgen. Network Orchestrators: these companies create a network of peers in which the participants interact and share in the value creation. They may sell products or services, build relationships, share advice, give reviews, collaborate, co-create and more. Examples include eBay, Red Hat, and Visa, Uber, Tripadvisor, and Alibaba. [12]

\section{E-Commerce Strategy}

Definition of the strategy from the perspective of what would be done by an organization is a comprehensive program to define and achieve its mission tumuan organizations and acted upon. Meanwhile, from the perspective of what is ultimately carried out by an organization, is the effort done from the beginning had been planned or not. The strategy is a response pattern organization committed to the environment over time [22]. The main aspects of the environment and the company is an industry, a company should strive to reach a sustainable competitive advantage, such as (1) continue to adapt to changes in external trends and internal capacity, capability and resources; and (2) the effective planning, implementation, and evaluation of the strategy that plays a major role [4].

\section{The Five Forces that Shape Industry Competition}

The purpose of the analysis of Porter's five forces is to determine competitive advantage and competitive advantage of companies [9]. Porter's Five Forces Model of competitive analysis is a widely used approach to develop a strategy in many industries [2]. According to Porter, competitive nature of the industry could be seen as a combination of top five strengths, namely Rivalry Among Existing Competitors, Threat of New Entrants, Threat of substitude Products or Services, Bargaining Power of Suppliers, Bargaining Power of Buyers [3].

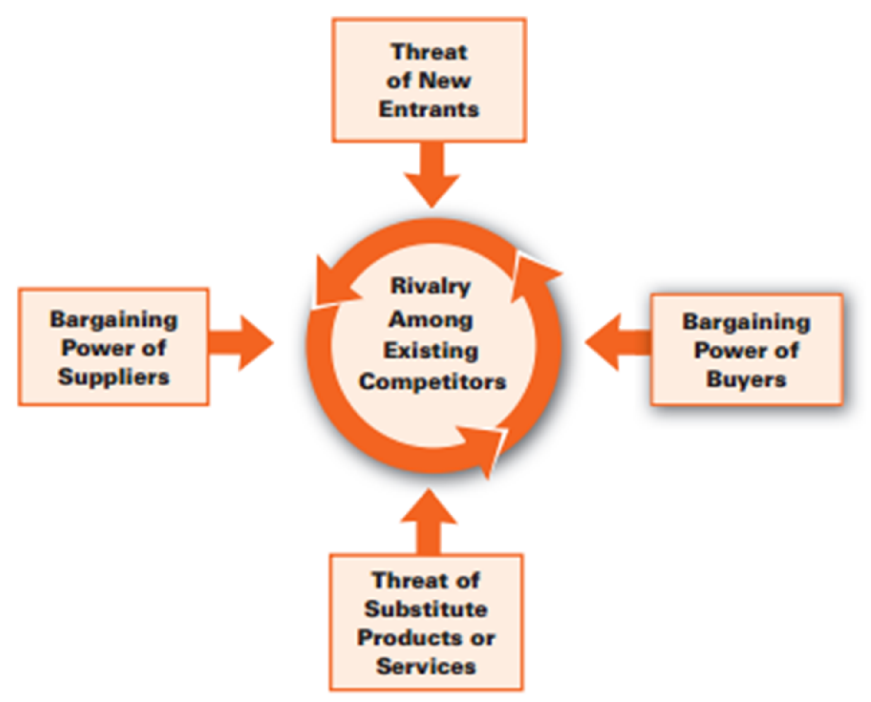

Fig. 1. The Five Forces That Shape Industry Competition [19]

1) Rivalry Among Existing Competitors

Competition between rival companies (Rivalry Among Existing Firms) is usually the greatest force in five competitive forces. Strategy pursued by the company can be successful if it 
provides a competitive advantage over rival companies run strategy. Change in strategy by one company may receive a counter-attack, such as lowering prices, improving quality, additional features, provision of services, extending the warranty, and increase advertising [2].

Competition is also increasing as customers can switch brands easily when the product is perishable, competing companies differ in terms of strategic, where they come from and the culture, mergers and acquisitions become common in an industry, as well as competition among similar companies intensifies, the company's profit decline, in some cases even create an industry becomes very unattractive [2]. Strategies run by one company can succeed only to the extent that the strategy provides a competitive advantage over the strategy pursued by the company's competitors [4].

The intensity of rivalry is greatest if : [19]

- Competitors are numerous or are roughly equal in size and power. In such situations, rivals find it hard to avoid poaching business. Without an industry leader, practices desirable for the industry as a whole go unenforced.

- Industry growth is slow. Slow growth precipitates fights for market share.

- Exit barriers are high. Exit barriers, the flip side of entry barriers, arises because of such things as highly specialized assets or management's devotion to a particular business.

- Rivals are highly committed to the business and have aspirations for leadership, especially if they have goals that go beyond economic performance in the particular industry.

- Firms cannot read each other's signals well because of lack of familiarity with one another, diverse approaches to competing, or differing goals.

2) Threat of New Entrants

The threat of entry of new entrants into the industry depends on the existing entry barriers, combined with the reaction of existing competitors that can be predicted by the new entrants [16]. If the barrier or obstacle is large and/or new entrants assume that there would be violent resistance of the old faces, then the threat of entry of new entrants will be low. There are six major sources of barriers that get in [16] that: economies of scale, product differentiation, capital requirements, the cost of switching suppliers, access to distribution channels, and indirect costs menguntungkn regardless of scale.

New entrants to an industry bring new capacity and a desire to gain market share that puts pressure on prices, costs, and the rate of investment necessary to compete. When the threat is high, incumbents must hold down their prices or boost investment to deter new competitors. In specialty coffee retailing for example, a relatively low entry barriers mean that Starbucks must invest aggressively in modernizing stores and menus. [19]

Newcomers are likely to fear expected retaliation if: [19]

- Incumbents have previously responded vigorously to new entrants

- Incumbents possess substantial resources to fight back, including 
excess cash and unused borrowing power, available productive capacity, or clout with distribution channels and customers

- Incumbents seem likely to cut prices because they are committed to retaining market share at all costs or because the industry has high fixed costs, which create a strong motivation to drop prices to fill excess capacity.

- Industry growth is slow so newcomers can gain volume only by taking it from incumbents

3) Threat of Substitude Products or Services

When the threat of substitutes is high, industry profitability suffers. Substitute products or services limit an industry's profit potential by placing a ceiling on prices. If an industry does not distance it self from substitutes through product performance, marketing, or other means, it will suffer in terms of profitability and often growth potential.[19]

All Performance Management in a competitive industry, in the broadest sense with the industries which produce analogs. Replacement products limits the potential profit of the industry with menetpkan price ceiling (ceiling price) which may be provided by the company in the industry. The more attractive prices offered by alternative replacement products, tighter restrictions on industry profits. Recognize products of substitution (replacement) is a matter of looking for other products that can perform the same function as the product in the industry. The position in the face of possible substitute products is a matter of collective industrial action.

Replacement products put an upper limit on the price that can be set before consumers move to replacement products. The strength of competition from substitute products is best measured by market share captured by the products, in addition to the company's plans to enhance the capacity and market penetration [4]

The threat of a substitute is high if: [19]

- It offers an attractive priceperformance trade-off to the industry's product. The better the relative value of the substitute, the tighter is the lid on an industry's profit potential.

- The buyer's cost of switching to the substitute is low.

4) Bargaining Power of Suppliers

Suppliers Bargaining Power (Bargaining power of supplier) can be a threat to the company that is obtaining input from a supplier in the event of the company's dependence on one supplier which become larger over time. Indicators that can be used to view the company's dependence to one supplier is an indicator of the concentration ratio (concentration ratio) to indicate the ratio between the amount of supply of a specific supplier with an overall value of inventories supplied by various suppliers.

Suppliers can use the bargaining power against industry participants with threat that will raise prices or reduce the quality of the products or services purchased. A strong supplier industry therefore can suppress the profitability to keep pace with the increase in the price [16]. 
Companies depend on a wide range of different supplier groups for inputs. A supplier group is powerful if:

- It is more concentrated than the industry it sells to.

- The supplier group does not depend heavily on the industry for its revenues

- Industry participants face switching costs in changing suppliers.

- Suppliers offer products that are differentiated.

- There is no substitute for what the supplier group provides.

- The supplier group can credibly threaten to integrate forward into the industry

5) Bargaining Power of Buyers

Powerful customers-the flip side of powerful suppliers-can capture more value by forcing down prices, demanding better quality or more service (there by driving up costs), and generally playing industry participants off against one another, all at the expense of industry profitability. Buyers are powerful if they have negotiating leverage relative to industry participants, especially if they are price sensitive, using their clout primarily to pressure price reductions.[19]

Bargaining power of consumers is also higher when purchased is a standard product or not differentiate. When the conditions are like this, consumers can often negotiate a sale price, warranty coverage, and accessory package up to a higher level [2]. In addition, consumers bid Strength is also greater if the purchased product standard or different. Competing company is offering the warranty may be longer or specialized services to gain customer loyalty that the bargaining power of customers is exceptional. Consumers often can negotiate selling prices, warranties, and accessories packing up to a certain level [4].

As with suppliers, there may be distinct groups of customers who differ in bargaining power. A customer group has negotiating leverage if: [19]

- There are few buyers, or each one purchases in volumes that are large relative to the size of a single vendor.

- The industry's products are standardized or undifferentiated. If buyers believe they can always find an equivalent product, they tend to play one vendor against another.

- Buyers face few switching costs in changing vendors

- Buyers can credibly threaten to integrate backward and produce the industry's product themselves if vendors are too profitable.

A buyer group is price sensitive if: [19]

- The product it purchases from the industry represents a significant fraction of its cost structure or procurement budget. Here buyers are likely to shop around and bargain hard, as consumers do for home mortgages. Where the product sold by an industry is a small fraction of buyers' costs or expenditures, buyers are usually less price sensitive.

- The buyer group earns low profits, is strapped for cash, or is otherwise under pressure to trim its purchasing costs.

- The quality of buyers' products or services is little affected by the 
industry's product. Where quality is very much affected by the industry's product, buyers are generally less price sensitive.

- The industry's product has little effect on the buyer's other costs. Here, buyers focus on price. Conversely, where an industry's product or service can pay for itself many times over by improving performance or reducing labor, material, or other costs, buyers are usually more interested in quality than in price.

\section{IDENTIFICATION OF RELEVANT BUSINESS MODELS}

Research Ljiljana Zekanovic-Korona and Jurica Grzunov entitled Evaluation of a Shared Digital Economy Adoption: Case of Airbnb states that Airbnb is an online service that is growing rapidly, which is an online travel agency for the wider community of clients that offer worldwide connections from hosts and customers seeking accommodation. The service itself is funded by the commission is charged from the host to the accommodation contracted totaling 3\% of the amount specified by the host and which is significantly less than the classic travel agency commission (20-30\%), and by a commission of $6 \%$ to $12 \%$ charged guest. Given that young people today are a good user of information technology, which is evident from the calculated TRI-responder indices, the rapidly growing popularity of the service Airbnb. This service is best characterized by ease of use, search and lots of good information about the host, and the method of payment security. Top rated component of this service is the ability to change the booking date, the service functions and the use of information and communication technologies used for booking. [10]

Research Daniel Guttentag entitled Airbnb: disruptive innovation and the rise of an informal tourism accommodation sectors related to the emergence Airbnb considering business processes are built in the technology sector modern Internet and allure that is different from similar competitors centered on cost savings, household facilities, and the potential for a more authentic local experience. [7]

Research June Liu, Robert J. Kauffman, and Dan Ma with the title of Competition, cooperation, and regulation: Understanding the evolution of the mobile payments ecosystem technology. This study examines the recent changes in the financial services sector payments, especially those related to mobile payments (m-payments) that allows new channels for customer payments for the purchase of goods and services, and other forms of economic exchange. The results show how they have been affected by competition, cooperation and regulation, and show some more universal pattern of technological innovation that offers insight into the development of ecommerce. [13]

Dean D. Lehr study entitled An Analysis of the Changing Competitive Landscape in the Hotel Industry Regarding related Airbnb competition analysis between the hotel and Airbnb in Sanfrancisco. Airbnb can be a meaningful experience between hosts and tourists (tenant), but there is no good side that sector tax, legal, regulatory, security code, and Airbnb became illegal with a competitive advantage. [11]

Analysis indicates that as of 2013, Network Orchestrators receive valuations two to four times higher, on average, than companies with the other business models. 
Further, trend data over the past decade indicates that this valuation gap is widening over time. We call this degree to which a business model drives the gap between revenues and valuation "the multiplier effect". [12]

\section{NETWORK ORCHESTRATORS LEAD THE PACK ON PRICE-TO-REVENUE}

AVERAGE MULTIPLIER (PRICE-TO-REVENUE RATIO) FOR THE S\&P 500 COMPANIES IN 2013

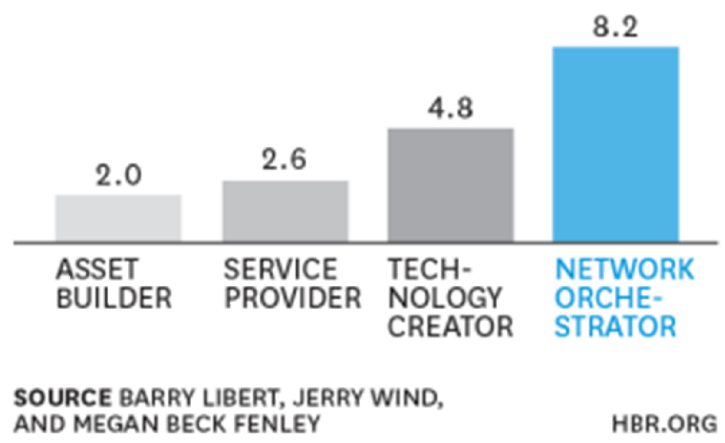

Fig. 2. Network Orchestrators Lead the Pack on Price-to-Revenue

\section{DISCUSSION OF THE RESULTS}

The data were processed by descriptive analysis based on data obtained from the Yag journals Airbnb analysis and based websites and mobile apps Airbnb, the results are as follows based on Porter's five forces analysis.

When Facebook acquired the messaging service WhatsApp for \$19 billion in the spring of 2014, the question on everyone's mind was, does the service really merit a valuation of almost 20 times projected revenues? Airbnb.com raised funding at a valuation of $\$ 10$ billion, which would make it worth nearly 20 times its revenues - and worth more than Hyatt Hotels or Wyndham Worldwide. [12]

When we looked beyond the impact of business model on price-to-revenue ratio, we also found that Network Orchestrators outperform companies with other business models on both compound annual growth rate and profit margin. We believe this occurs because the value creation performed by the network on behalf of the organization reduces the company's marginal cost, as described in Jeremy Rifkin's The Zero Marginal Cost Society. For example, TripAdvisor.com benefits from its customer's reviews and Airbnb leverages its network's housing assets. [12]

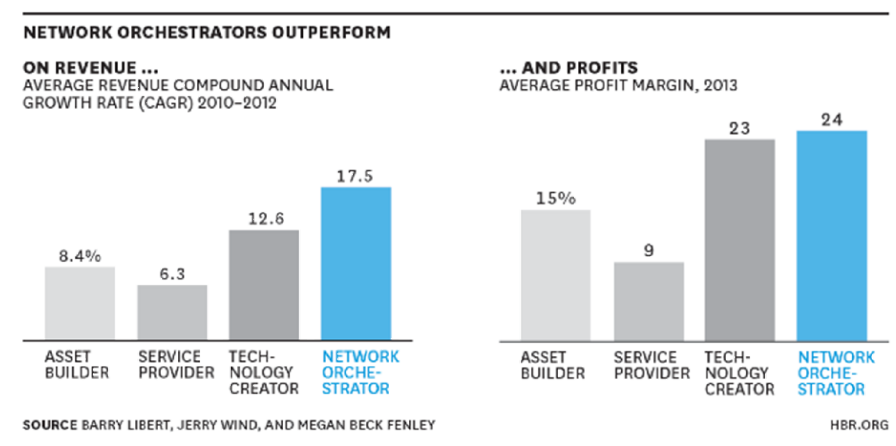

Fig. 3. Network Orchestrators Outperform

The company (Airbnb) now operates in 190 countries and 28,000 cities, and its founders expect the service to grow to 100 million annual bookings and revenue of $\$ 1$ billion. (The site charges both host and guest service fees for each stay, based on a percentage of the total price.) This idea of peer-to-peer commerce, or the "sharing economy" as it is sometimes known, has spawned a new breed of innovations. Startups are now facilitating short-term borrowing of such expensive but often under-utilized possessions as apartments and homes, cars (or just a ride), power tools, and even, on sites such as TaskRabbit, personal expertise. [5]

Airbnb, it turns out, isn't simply matching buyers and sellers. The service also requires hosts to provide verifiable identification, and offers guests 24/7 customer service in case anything goes wrong. Users also rate and review each other. Payments go directly to Airbnb, not the host. And the company provides a 
$\$ 1,000,000$ insurance policy against damage caused by guests. These are precisely the kind of quality and safety controls that city regulators enforce for traditional lodgings, and for which they collect taxes. But using the same technology that makes the service possible, Airbnb has replicated much of the regulatory structure in what is arguably a more efficient format

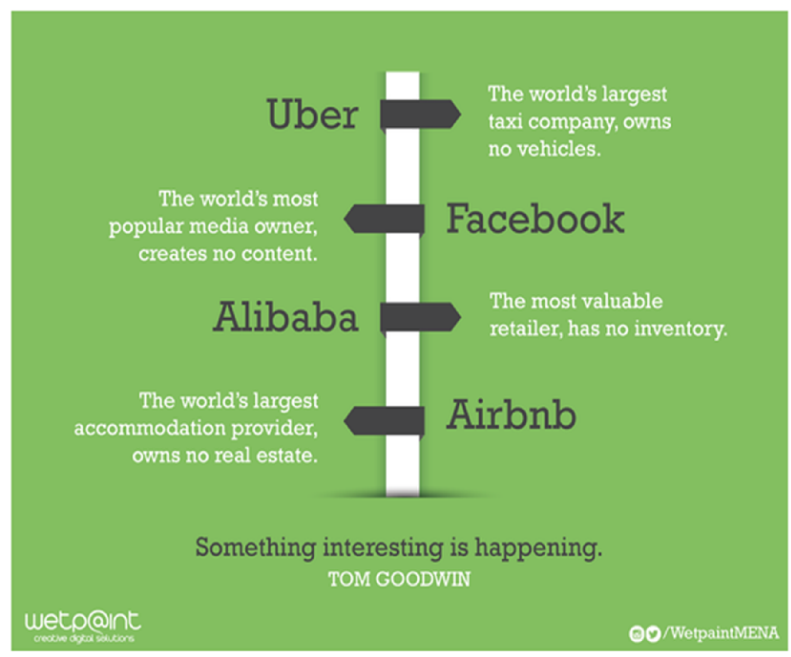

Image Credit: WetPaint MENA

Fig. 4. These Companies Prove You Don't

Need to 'Own' Anything to be

Successful.

Airbnb, for redesigning the hotel experience. Airbnb, the home and apartment rental service, can boast over 10 million stays last year, andas reported in Fast Company tripled revenue to an estimated $\$ 250$ million. Key to their success is their stellar user experience design: parsing listings on Airbnb's site is akin to flipping through a beautiful travel magazine and the company is poised to become a hospitality company and a travel guide company. [21]

Airbnb provides convenience in its website, portability conducted by Airbnb consists of the features of the language, which facilitates the Indonesian people to post their rooms (for rent) and also tenant easier to find. On the side Airbnb portability also be accessed via apps or website, the following test to see top web based browser (from whom so). Even the Airbnb website using local domain for a special state, https://www.airbnb.co.id/

The results compare with rivals from existing competitors Among Airbnb is Homeaway using analytic data SimilarWeb

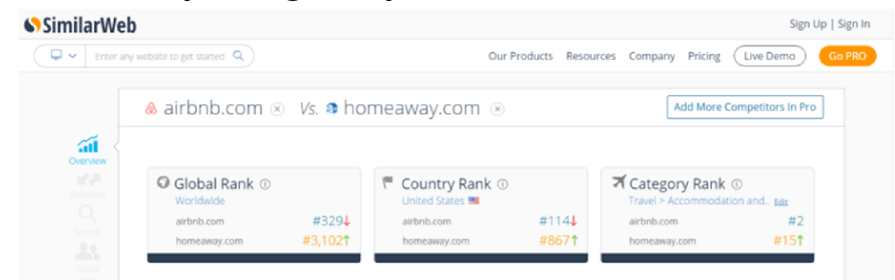

Fig. 5. Results global rank, country rank and rank category

Results global rank, country rank and rank category. Shows that Airbnb is well ahead of its competitors.

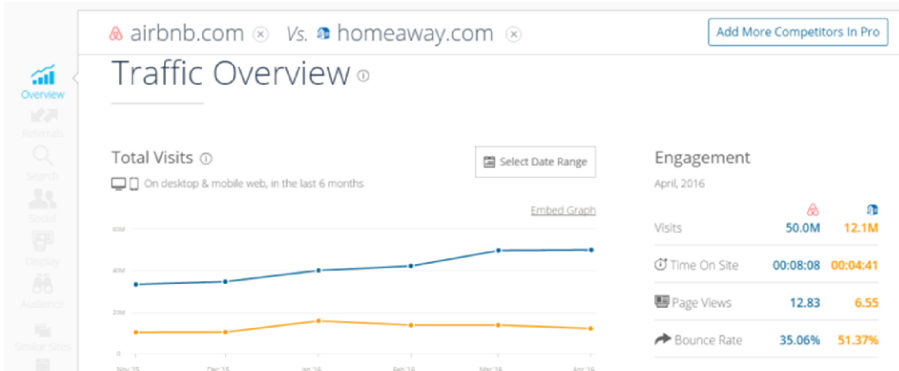

Fig. 6. Result of Traffic Overview Total Visits

Traffic Overview of the results showed that the total visits to the Airbnb of november 2015 until April 2016 has increased each month.

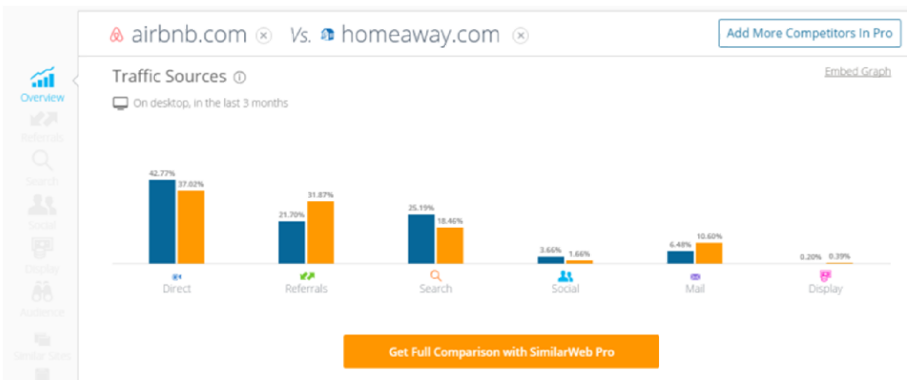

Fig. 7. Result of Traffic Sources

On the results of Traffic Sources, Homeaway superior Airbnb.

Then using AIRDNA, the author uses to analyze how the level of activity Airbnb in Indonesia, one that my analysis is on the 
island of Bali, Indonesia.

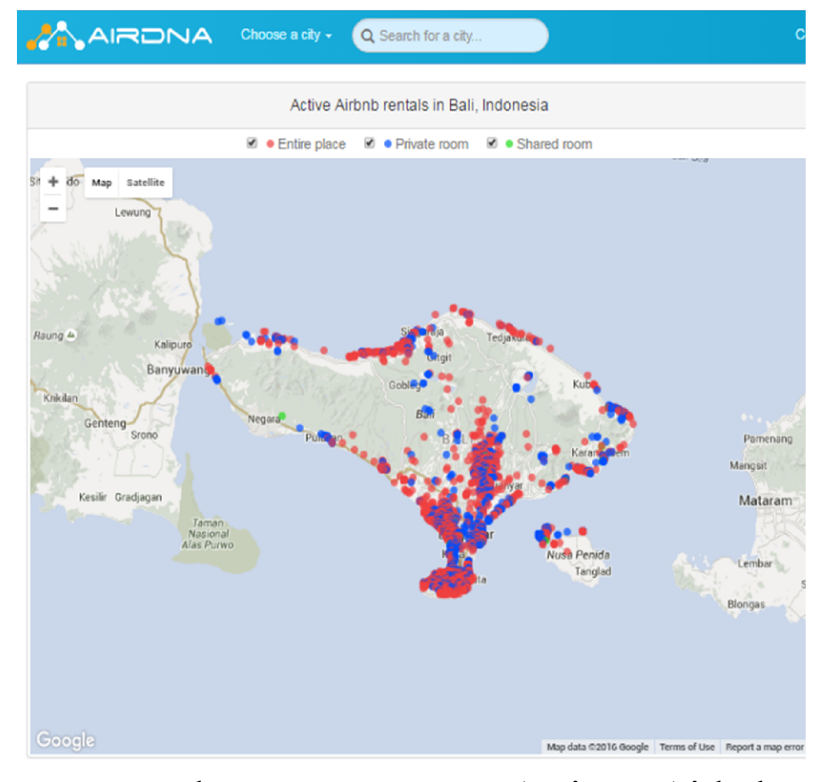

Fig. 8. Result How Many Active Airbnb rentals in Bali, Indonesia

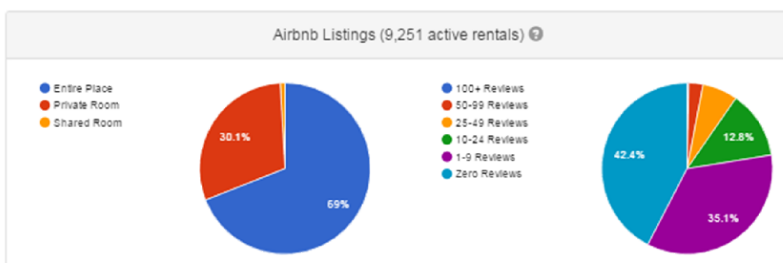

Fig. 9. Result Airbnb Listings (9.251 active rentals in Bali, Indonesia)
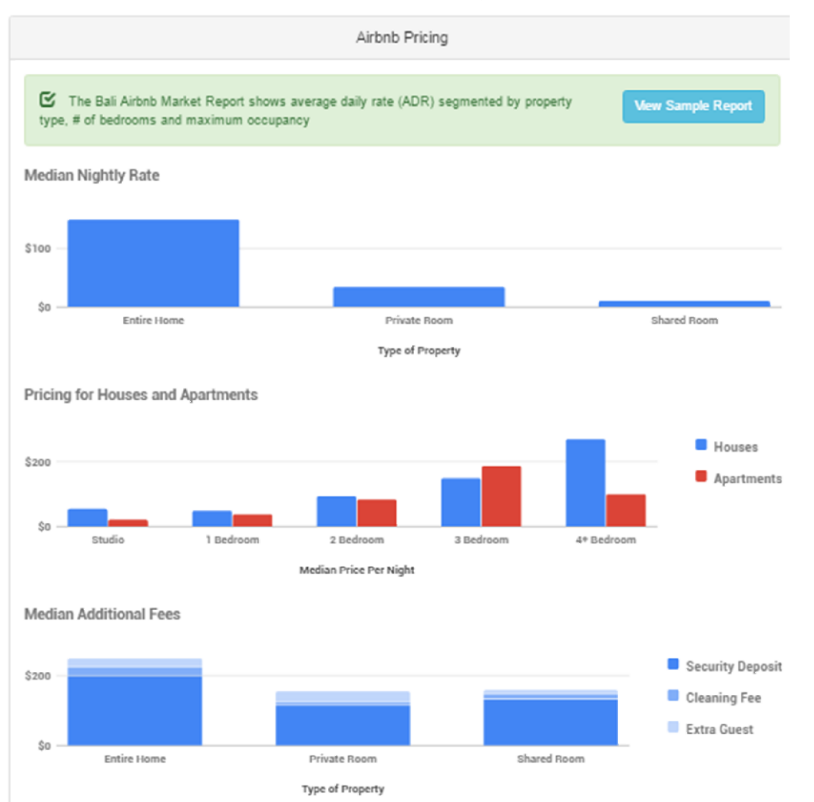

Fig. 10. Result Airbnb Pricing in Bali, Indonesia

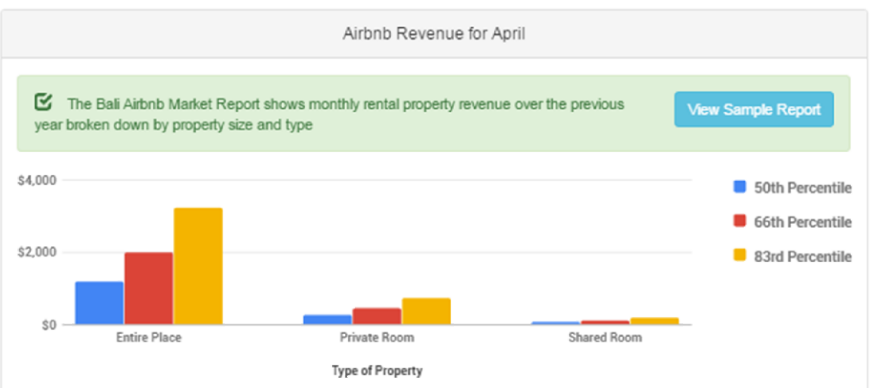

Fig. 11. Result Revenue Airbnb for April in Bali, Indonesia

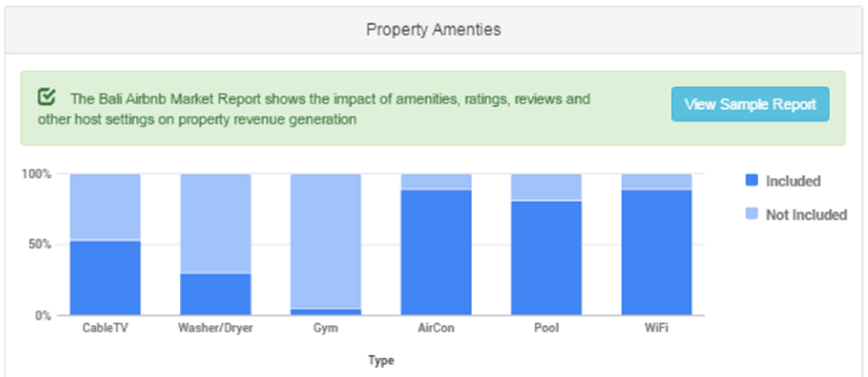

Fig. 12. Result Property Amenties

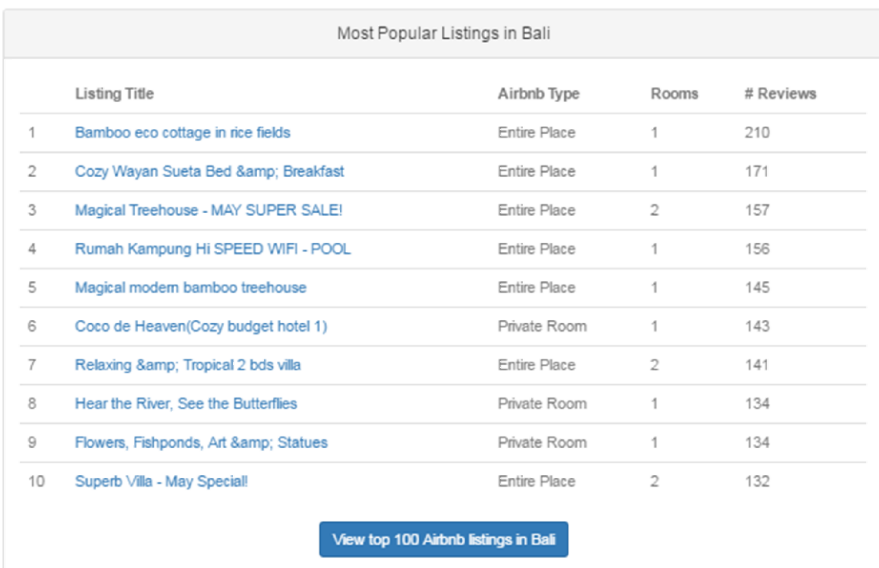

Fig. 13. Result Most Popular Listings in Bali

\section{Rivalry Among Existing Competitors}

As a service provider specialty, Airbnb also got competition against competitors such as HomeAway. To handle such competition Airbnb simplify the existing system in terms of tenants Airbnb lodging and accommodation providers, eg in terms of both payment and booking. Hopefully, by the convenience of users remain faithful to Airbnb. But it is still a problem today that room providers declared illegal for not paying taxes like the rooms in the hotel.

Based on test results Airbnb website 
ahead of its competitors, namely HomeAway, Airbnb website get results obtained grade A category First Byte Time, Keep-alive Enabled, Compress Transfer, Compress Images.

\begin{tabular}{|c|c|c|c|c|}
\hline Web Page Performance Test for & A & A & A & A \\
\hline
\end{tabular}

Fig. 14. Results webpagetest.org to measure website Airbnb

Web Page Performance Test for

www.homeaway.co.id? _hanr=HAUS

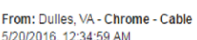

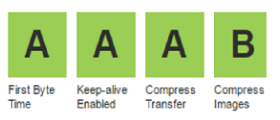

Fig. 15. Results webpagetest.org to measure website HomeAway

\section{Threat of New Entrants}

In anticipation of a new competitor Airbnb addition to the ease of mobile payment transactions in particular. Airbnb also renewed for faster system performance and also on the face to make it more appealing to the eye.

The indicators used in the analysis below [6].

- The capital requirements, capital requirements for opening a business service online travel agent is quite large, where Airbnb takes investors in the early development of a system complexity and captures the level of confidence both home (which rents the inn) and visitors who use the services of Airbnb on their way. Low threat levels.

- Indicators way sufficient capital requirements, capital requirements with an adequate way of investment and pitching to investors and come and offer people closest to her room penyewakan. High threat level.

- level indicator of customer loyalty, loyalty level is flexible depending on the suitability of consumers to the company, when seen from the rating on apps, it can be concluded high level of loyalty. The threat level Medium.

- The formation of customer loyalty, customer loyalty is not formed itself but because of the service and the good performance of the company. So far the company has committed to continue to meet customer needs so as to satisfy the customer. The threat level is being.

- Indicators of access to distribution channels, access to distribution channels using online ordering, ranging from booking to pay. High threat level.

- The cost to the needs of distribution channels, in collaboration with a third party to handle the payment process. The threat level is being.

- Indicators of government policy, industry growth is inseparable from the policy of the government, the government has simplify licensing and conditioning industry sector to grow. Low threat levels.

- The impact of government policies, government policies have a considerable impact. The threat level is being.

\section{Threat of substitude Products or Services}

To anticipate a similar competitors like traveloka since the beginning Airbnb provides convenience and comfort for the tenants as well as specialty providers. So hopefully the users will always use Airbnb service providers favorite lodging.

Indicators used by [6], namely the level of demand for replacement products and the ease of getting a replacement product. 
TABLE I. SEARCH RESULTS APPLICATION IN TRAFFIC MOBILE OPERATING SYSTEM

\begin{tabular}{|l|l|l|l|l|}
\hline Application & BlackBerry & IOS & Android & Windows Phone \\
\hline Airbnb & $\sqrt{ }$ & $\sqrt{ }$ & $\sqrt{ }$ & $\sqrt{ }$ \\
\hline HomeAway & $\sqrt{ }$ & $\sqrt{ }$ & $\sqrt{ }$ & $\sqrt{ }$ \\
\hline
\end{tabular}

TABLE II. RESULTS ANALYSIS OF SUBSTITUTE PRODUCTS THREATS

\begin{tabular}{|c|c|c|c|}
\hline No & Indicator & Analysis & Conclusion \\
\hline 1 & $\begin{array}{l}\text { The level of } \\
\text { demand for } \\
\text { replacement } \\
\text { products }\end{array}$ & $\begin{array}{l}\text { The level of demand for replacement products } \\
\text { are not too high, where people still access } \\
\text { requests and orders at Airbnb is increasing } \\
\text { every year }\end{array}$ & $\begin{array}{l}\text { threats are } \\
\text { being }\end{array}$ \\
\hline 2 & $\begin{array}{l}\text { Ease of getting a } \\
\text { replacement } \\
\text { product }\end{array}$ & $\begin{array}{l}\text { If just booked the hotel a lot, but the comfort } \\
\text { and experience yag obtained if a message on } \\
\text { Airbnb is still superior and yet that rival it. }\end{array}$ & low threat \\
\hline
\end{tabular}

\section{Bargaining Power of Buyers}

For specialty care providers by highlighting the generosity of the rental fee. Airbnb is still much in demand in many circles as a backpacker, the middle class, and upper class who want to rent a room unique. Because in general, customers are looking for inexpensive lodging and besides looking for unique.

Airbnb websites including highly interactive, because it gives a lot of information that is very easy to learn for the first visitors, as in figure 16.

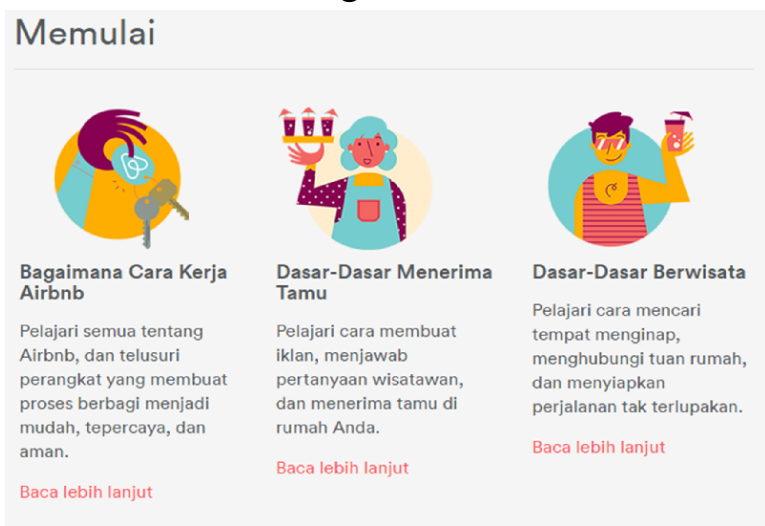

Fig. 16. Tour guide of the Airbnb website
If seen from the many reviews and app downloads on google play.
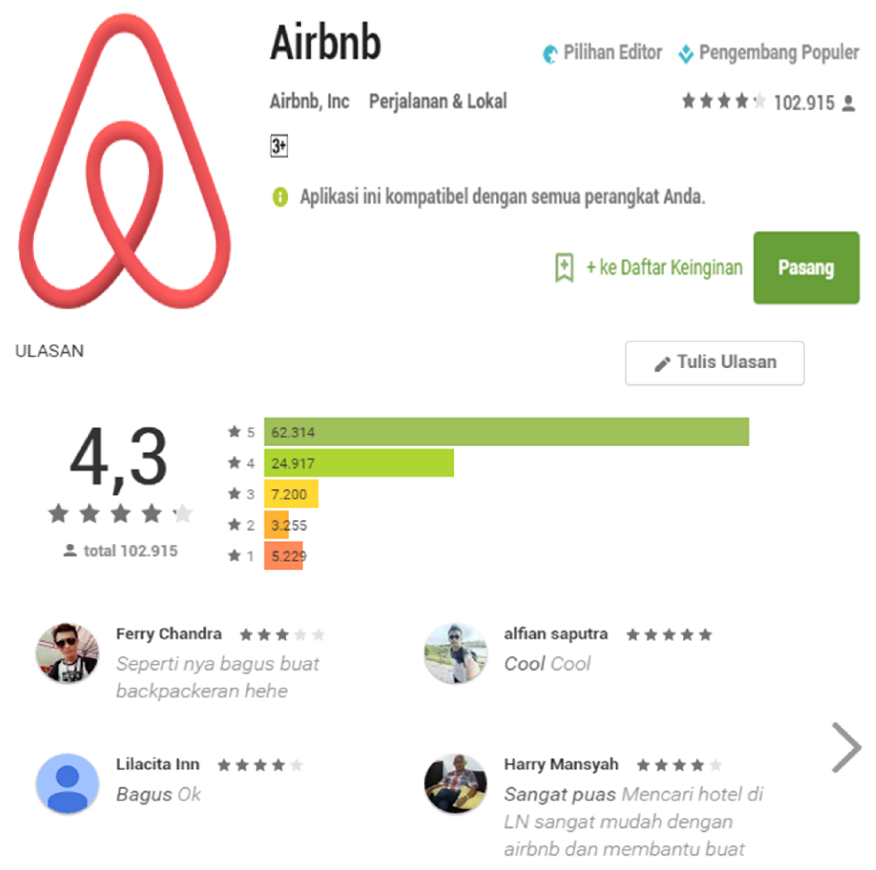

Fig. 17. Results Review Airbnb app on Google Play 